Research Article

\title{
Trend of Caesarean Section in a Tertiary Care Hospital: A Prospective Observational Study from Andaman and Nicobar Islands, India
}

\author{
Abhishek Malakar', Shiv Shankar Singh'2, Shreya Barik², Dhanisha S Awaradi ${ }^{4}$ \\ ${ }^{1}$ Assistant Professor, ${ }^{3}$ Senior Resident, ${ }^{4}$ Internee, Department of Obstetrics and Gynaecology, ANIIMS, Port Blair, India. \\ ${ }^{2}$ Associate Professor, Department of General Medicine, ANIIMS, Port Blair, India. \\ DOI: https://doi.org/10.24321/2454.8642.201910
}

\section{I $\quad \mathbf{N} \quad \mathbf{F}$}

\section{Corresponding Author:}

Shiv Shankar Singh, Department of General Medicine, ANIIMS, Port Blair, India.

E-mail Id:

diraniims@gmail.com

Orcid Id:

https://orcid.org/0000-0001-8544-6260

How to cite this article:

Malakar A, Singh SS, Barik S et al. Trend of Caesarean Section in a Tertiary Care Hospital: A Prospective Observational Study from Andaman and Nicobar Islands, India. Rec Adv Path Lab Med 2019; 5(2): 22-26.

Date of Submission: 2019-07-25

Date of Acceptance: 2019-09-03

\section{$\begin{array}{llllllll}\mathbf{A} & \mathbf{B} & \mathbf{S} & \mathbf{T} & \mathbf{R} & \mathbf{A} & \mathbf{C} & \mathbf{T}\end{array}$}

Background: Caesarean Section (CS) is one of the most commonly performed operations in obstetrics. The rate of caesarean section is increasing throughout the world and not surprisingly also in India. Caesarean sections are done due to various reasons, and often used liberally. We conducted this study to assess the rate of Caesarean deliveries and its indications in a tertiary care hospital in Andaman and Nicobar Islands, India.

Methods: This was a prospective observational study where data was collected for all Caesarean sections performed from January 2018 to December 2018 and the data was statistically analysed by MS Excel and frequency distribution tables.

Result: There were total 2646 deliveries over the study period of one year with caesarean rate of $38.51 \%$. $73.61 \%$ were emergency CS. Most common indications of CS were post caesarean pregnancy $(24.73 \%)$ and fetal distress (15.11\%) and more than $75 \%$ were primary caesarean section.

Conclusion: A high CS rate with a high percentage of primary caesarean section was observed in this study. Indications included mainly post caesarean pregnancies, fetal distress and non-reassuring cardiotocography, portraying the low threshold for CS. Standard national protocols and practice of evidence-based obstetrics along with maintenance of institutional audits are needed to decrease the escalating CS rate.

Keywords: Andaman and Nicobar, CS Rate, Indications of CS, Primary Caesarean Section, Trend

\section{Introduction}

Caesarean delivery is one of the most common operations in present day obstetrics. Although according to $\mathrm{WHO}$, ideal Caesarean Section (CS) rate should not be more than 10-
$15 \%$, there has been steady rise in rate of caesarean section rates both in developed as well as developing countries over the past few years. ${ }^{1}$ The 2012 US caesarean delivery rate was $32.8 \%$ whereas in United Kingdom, it was $24.1 \%$ in $2014 .^{2,3}$ The reasons for this increase are multifaceted. Foetal 
distress, especially its detection by continuous electronic foetal monitoring, more liberal use of caesarean section for breech presentation, preference of abdominal delivery in a growth-restricted foetus, delayed childbearing and growing cases of infertility, increasing maternal body mass, multiple gestation especially with advances in in-vitro fertilization, better survival of premature new-born, and improved safety of caesarean section are the commonly cited reasons. ${ }^{4}$

Although there have been studies from different parts of India regarding trends of caesarean section, there have been no similar studies from Andaman and Nicobar Islands. Our institute, Andaman and Nicobar Islands Institute of Medical Sciences (ANIIMS) is the only tertiary care hospital here and hence, we conducted this study to reflect the scenario in this part of India. Our aim was to determine the caesarean section rate and its most common indications in this institute, as data from this part of the country is sparse. The objective was to note the trends of CS in this area, which shall go a long way in identifying the factors which may help reducing primary caesarean section rate and its complications.

\section{Materials and Methods}

This was a prospective observational study conducted in Andaman and Nicobar Islands Institute of Medical Sciences, a tertiary care hospital in Andaman and Nicobar Islands. We collected data of all the caesarean sections done over one year, from January 2018 to December 2018. The total number of deliveries over the study period of one year was collected and caesarean section rate was determined by total number of caesarean deliveries out of total deliveries. We noted the demographic parameters like age, parity, religion and obstetrical parameters like gestational age at CS, types and indications of CS. We also collected retrospective data from our medical record section regarding number of CS and total deliveries over past few years. We presented the data in table formats and analysed using MS Excel and frequency distribution tables. Informed consent was obtained from individual participants included in the study. The study was approved by the institutional ethical committee.

\section{Result}

There were total 2646 deliveries over one year of study period, out of which 1019 were caesarean delivery, which makes the rate of caesarean section as $38.51 \%$, with incidence of primary caesarean section $75.27 \%$. Approximately three fourth of the total cases (73.6\%) were emergency CS done due to various indications (Table 1).

Table 2 shows the demographic parameters of the women undergoing CS. Age wise, majority (645 out of 1019 women) were in the age group of 21-30 years with approximately one out of twenty women being of age over thirty-five years. Only $15.01 \%$ women underwent CS before 37 completed weeks mostly due to maternal indications like severe preeclampsia or ante partum haemorrhage. More than half of them were of Hindu community. $53.37 \%$ of all women were primigravida.

Table I.Rate of caesarean section

\begin{tabular}{|c|c|c|c|}
\hline \multicolumn{2}{|c|}{ Parameters } & $\begin{array}{c}\text { No. of } \\
\text { deliveries } \\
\text { (n=2646) }\end{array}$ & $\begin{array}{c}\text { Percentage } \\
\text { (\%) }\end{array}$ \\
\hline \multirow{2}{*}{$\begin{array}{c}\text { Mode of } \\
\text { deliveries } \\
(n=2646)\end{array}$} & $\begin{array}{c}\text { Caesarean } \\
\text { delivery }\end{array}$ & 1019 & $38.51 \%$ \\
\cline { 2 - 4 } & $\begin{array}{c}\text { Vaginal } \\
\text { delivery }\end{array}$ & 1627 & $61.49 \%$ \\
\cline { 2 - 4 } & Total & 2646 & $100 \%$ \\
\hline \multirow{2}{*}{$\begin{array}{c}\text { Type of CS } \\
\text { (n=1019) }\end{array}$} & Elective & 269 & $26.4 \%$ \\
\cline { 2 - 4 } & Emergency & 750 & $73.6 \%$ \\
\hline \multirow{2}{*}{$\begin{array}{c}\text { Primary/ } \\
\text { repeat CS }\end{array}$} & Primary CS & 767 & $75.27 \%$ \\
\cline { 2 - 4 } & Repeat CS & 252 & $24.73 \%$ \\
\hline
\end{tabular}

Table 2.Demographic parameters

\begin{tabular}{|c|c|c|c|}
\hline \multicolumn{2}{|c|}{ Parameter } & $\begin{array}{c}\text { Number } \\
\text { (n=1019) }\end{array}$ & $\begin{array}{c}\text { Percentage } \\
\text { (\%) }\end{array}$ \\
\hline \multirow{4}{*}{ Age } & $\leq 20$ years & 112 & $11 \%$ \\
\cline { 2 - 4 } & $21-25$ years & 340 & $33.37 \%$ \\
\cline { 2 - 4 } & $26-30$ years & 305 & $29.93 \%$ \\
\cline { 2 - 4 } & $31-35$ years & 204 & $20.02 \%$ \\
\cline { 2 - 4 } & $\begin{array}{c}\text { More than } \\
35 \text { years }\end{array}$ & 58 & $5.68 \%$ \\
\hline \multirow{4}{*}{$\begin{array}{c}\text { Gestational } \\
\text { age }\end{array}$} & $<37$ weeks & 153 & $15.01 \%$ \\
\cline { 2 - 4 } & $\geq 37$ weeks & 866 & $84.99 \%$ \\
\hline \multirow{3}{*}{ Parity } & Nulliparous & 544 & $53.37 \%$ \\
\cline { 2 - 4 } & Multiparous & 475 & $46.63 \%$ \\
\hline \multirow{4}{*}{ Religion } & Hindu & 577 & $56.62 \%$ \\
\cline { 2 - 4 } & Muslim & 204 & $20.02 \%$ \\
\cline { 2 - 4 } & Christian & 169 & $16.58 \%$ \\
\cline { 2 - 4 } & Others & 69 & $6.78 \%$ \\
\hline
\end{tabular}

We analysed the different indications of caesarean section and it was found that Post Caesarean section pregnancy was the commonest indication (24.73\%) followed by foetal distress (15.11\%). Malpresentation, non-progress of labour, severe preeclampsia and failure of induction were the next common indications. Other foetal indications were IUGR, oligohydramnios and cord prolapse. Maternal request for CS was also an indication in twelve cases in our study (Table 3). 
Table 3.Various indications for caesarean section

\begin{tabular}{|c|c|c|}
\hline Indication & $\begin{array}{c}\text { No. of } \\
\text { cases } \\
(n=1019)\end{array}$ & $\begin{array}{c}\text { Percentage } \\
(\%)\end{array}$ \\
\hline $\begin{array}{c}\text { Post Caesarean section } \\
\text { pregnancy (with scar } \\
\text { tenderness/ not fit for VBAC) }\end{array}$ & 252 & $24.73 \%$ \\
\hline $\begin{array}{c}\text { Meconium stained liquor in } \\
\text { first stage of labour with fetal } \\
\text { distress }\end{array}$ & 154 & $15.11 \%$ \\
\hline Malpresentation & 130 & $12.76 \%$ \\
\hline $\begin{array}{l}\text { Obstructed labour/ Second } \\
\text { stage caesarean section }\end{array}$ & 90 & $8.83 \%$ \\
\hline Severe preeclampsia & 90 & $8.83 \%$ \\
\hline $\begin{array}{l}\text { Non progress in first stage of } \\
\text { labour }\end{array}$ & 88 & $8.64 \%$ \\
\hline Failure of induction & 82 & $8.05 \%$ \\
\hline $\begin{array}{c}\text { Severe oligohydramnios with } \\
\text { fetal distress }\end{array}$ & 53 & $5.2 \%$ \\
\hline $\begin{array}{c}\text { Intra Uterine growth } \\
\text { Restriction (IUGR) with fetal } \\
\text { distress }\end{array}$ & 30 & $2.94 \%$ \\
\hline Ante partum haemorrhage & 16 & \multirow{3}{*}{$1.57 \%$} \\
\hline Placenta praevia & 12 & \\
\hline Abruptio placentae & 04 & \\
\hline Contracted pelvis & 14 & $1.37 \%$ \\
\hline Maternal request & 12 & $1.18 \%$ \\
\hline $\begin{array}{c}\text { Precious Pregnancy in case of } \\
\text { infertility }\end{array}$ & 06 & $0.59 \%$ \\
\hline Cord prolapse & 02 & $0.2 \%$ \\
\hline
\end{tabular}

\section{Discussion}

The rapid increase in caesarean birth rates over the past few years all over the world without clear evidence of concomitant decreases in maternal or neonatal morbidity or mortality raises significant concern that caesarean delivery is overused..$^{5}$

There is a wide variation of caesarean section rates all over India as seen from various studies shown in Table 4. The reason behind this wide variation is that the indications of caesarean sections vary among institutions as there is no standard classification system and the definitions are also not standardized. ${ }^{6,7}$

In our study, we found the rate of CS was $38.51 \%$ which was on the higher side and more than double of the accepted upper value of $15 \% .{ }^{1}$ The reason behind this was our institute being the only referral centre of the whole
Andaman and Nicobar Islands, many high risk cases and also cases in late stages of labour were referred here due to inter island transportation delay. Our study result was similar to a study from east India, where the CS rate was $35.45 \%$ in 2017-2018. ${ }^{8}$

Table 4.Caesarean section rates from different studies of India

\begin{tabular}{|c|c|c|c|}
\hline Zone & Place of Study & Period of Study & $\begin{array}{l}\text { Rate } \\
\text { of CS }\end{array}$ \\
\hline \multirow{2}{*}{$\begin{array}{l}\text { Eastern } \\
\text { India }\end{array}$} & $\begin{array}{c}\text { Bhubaneswar, } \\
\text { Odisha }^{8}\end{array}$ & $\begin{array}{c}\text { May } 2017-A p r i l \\
2018\end{array}$ & 35.45 \\
\hline & Sonitpur, Assam ${ }^{9}$ & $\begin{array}{c}\text { Jan 2015-Dec } \\
2015\end{array}$ & 27.60 \\
\hline \multirow{2}{*}{$\begin{array}{l}\text { Northern } \\
\text { India }\end{array}$} & $\begin{array}{c}\text { Dehradun, } \\
\text { Uttarakhand }\end{array}$ & $\begin{array}{c}\text { Jan 2015-Dec } \\
2015\end{array}$ & 31.40 \\
\hline & $\begin{array}{c}\text { Vallah, Amritsar, } \\
\text { Punjab }{ }^{11}\end{array}$ & $\begin{array}{c}\text { May 2015-Apr } \\
2016\end{array}$ & 33.20 \\
\hline \multirow{2}{*}{$\begin{array}{l}\text { Western } \\
\text { India }\end{array}$} & $\begin{array}{c}\text { Jaipur, } \\
\text { Rajasthan }^{12}\end{array}$ & $\begin{array}{c}\text { Jan 2016-Dec } \\
2016\end{array}$ & 32.46 \\
\hline & $\begin{array}{l}\text { Vadodara, } \\
\text { Gujarat }^{13}\end{array}$ & $\begin{array}{c}\text { Jan 2013-Dec } \\
2013\end{array}$ & 28.87 \\
\hline \multirow{2}{*}{$\begin{array}{l}\text { Southern } \\
\text { India }\end{array}$} & $\begin{array}{c}\text { Visakhapatnam, } \\
\text { Andhra Pradesh }{ }^{14}\end{array}$ & $\begin{array}{c}\text { Jan 2014-Dec } \\
2014 \\
\end{array}$ & 25.66 \\
\hline & $\begin{array}{l}\text { Maduranthagam, } \\
\text { Tamil Nadu }{ }^{15}\end{array}$ & $\begin{array}{c}\text { Jan 2011-Dec } \\
2014\end{array}$ & 12.5 \\
\hline
\end{tabular}

Other than total CS rate, another trend of CS is the rise in the rate of primary caesarean section. In our study, we found 767 out of 1019 (75.27\%) women underwent primary caesarean section. This rate was similar to a study on primary caesarean section rates by Erika Desai et al (74.66\%) but more than the result by Jain M, Patel A (55.8\%) and Das RK et al. (63.41\%). ${ }^{8,16,17}$ This high percentage of primary caesarean section was obstetrically significant as this paves way for more repeat caesarean deliveries in future. Demographically, most women undergoing CS were in the age group of 21-30 years and were primigravida as found by other studies. ${ }^{16,17}$

Most of the CS were emergency CS with post caesarean pregnancy being the most common indication overall. This might be due to the fact that vaginal birth after caesarean was not widely practised in our institute. This finding was exactly similar to some of the prior studies, where post CS pregnancies constitute about $23-40 \%$ of all the CS done. ${ }^{8,9,12,18}$ Foetal distress was the second most common indication (15.11\%) as also found by Jawa A et al. and Bade $P$ et al. in their studies. ${ }^{12,19}$ As we had no provision for foetal scalp blood sampling, hence maximum non-reactive NST findings in early labour were taken for CS. Altogether 178 cases (including both first stage and second stage arrest) out 
of 1019 i.e. $17.47 \%$ were taken for CS for arrest of labour, which was exactly similar to the finding of a study from western India (17.6\%). ${ }^{19}$ There was a substantial amount $(8.83 \%)$ of CS done in view of obstructed labour or second stage caesarean section. This is attributed to the difficulty to access tertiary health care from distant islands in this area. Almost all of obstructed labour cases were referred cases from periphery.

Table 5.Rising trend of CS all over India

\begin{tabular}{|c|c|c|c|}
\hline Zone & Place of Study & Time Period & $\begin{array}{c}\text { Change } \\
\text { in Rate of } \\
\text { CS }\end{array}$ \\
\hline $\begin{array}{c}\text { Northern } \\
\text { India }\end{array}$ & $\begin{array}{c}\text { Agroha, } \\
\text { Haryana }^{20}\end{array}$ & $2007-2012$ & $\begin{array}{c}31.0 \% \text { to } \\
51.1 \%\end{array}$ \\
\hline $\begin{array}{c}\text { Southern } \\
\text { India }\end{array}$ & $\begin{array}{c}\text { Visakhapatnam, } \\
\text { Andhra } \\
\text { pradesh }^{14}\end{array}$ & $2004-2014$ & $\begin{array}{c}16.14 \% \text { to } \\
25.66 \%\end{array}$ \\
\hline $\begin{array}{c}\text { Western } \\
\text { India }\end{array}$ & $\begin{array}{c}\text { Mumbai, } \\
\text { Maharashtra }\end{array}$ & $2001-2011$ & $\begin{array}{c}17.15 \% \text { to } \\
29.93 \%\end{array}$ \\
\hline $\begin{array}{c}\text { Eastern } \\
\text { India }\end{array}$ & $\begin{array}{c}\text { Kolkata West }_{\text {Bengal }}^{22} \\
\text { Bentern }^{21}\end{array}$ & $1973-2012$ & $\begin{array}{c}9.50 \% \text { to } \\
40.10 \%\end{array}$ \\
\hline $\begin{array}{c}\text { Western } \\
\text { India }\end{array}$ & Gujarat $^{13}$ & $2004-2013$ & $\begin{array}{c}23.48 \% \text { to } \\
28.87 \%\end{array}$ \\
\hline
\end{tabular}

There is a rising trend of CS reported from all over India over the last decade from $16 \%$ to $40 \%$ (approximately) (Table $5)$. We had collected retrospective data regarding CS rate in our institute from medical record section, which clearly revealed a similar trend of increasing of CS rate over past few years from $34.46 \%$ in 2014 to $38.51 \%$ in 2018.

\section{Conclusion}

In an era where medical science has significantly advanced with more institutional deliveries being conducted in developing countries like India, more efforts should be made to provide a safer vaginal delivery to mothers that promises a better obstetric future. Contrary to this, we have seen a rising rate of caesarean sections, with obstetricians taking a no risk policy, sometimes abandoning trial of labour. This study found the CS rate as $38.51 \%$ whereas the rate of primary CS was $75.27 \%$. It looked to scrutinize possible areas which contributed to this high CS rate. With several studies identifying the main contributory factors from nearly all over the country, it is the need of the hour for a common national guideline and protocols especially for amendable indications like non-reactive non-stress test, which can help to bring down the alarming increase in CS without compromising on maternal and foetal wellbeing.

\section{Acknowledgement}

Authors would like to acknowledge the Medical Record
Department of our institution for allowing access to the record of deliveries of previous years.

\section{Funding: None \\ Conflict of Interest: None \\ References}

1. WHO Statement on caesarean section rates. 2015. WHO reference number: WHO/RHR/15.02. Available from: http://www.who.int/reproductivehealth/publications/ maternal perinatal health/cs-statement/en.

2. National vital statistics report. 2012; 62(9). Available from: https://www.cdc.gov/nchs/products/nvsr.htm.

3. WHO Euro Health for all database. 2014. Available from: http://data.euro.who.int/hfadb/(53).

4. Tollanes MC. Increased rate of Caesarean sections - causes and consequences. Tidsskr Nor Laegeforen 2009; 129(13): 1329-1331.

5. Gregory KD, Jackson S, Korst L et al. Cesarean versus vaginal delivery: Whose risks? Whose benefits? Am J Perinatol 2012; 29: 7-18.

6. Stanton C, Ronsmans C. Recommendations for routine reporting on indications for caesarean delivery in developing countries. Birth 2008; 35: 204-11.

7. Torloni MR, Betran AP, Souza JP et al. Classification for caesarean section: a systematic review. PLoS One 2011; 6: e1456.

8. Das RK, Trimal Subudhi K, Mohanty RK. The rate and indication of caesarean section in a tertiary care teaching hospital eastern India. International Journal of Contemporary Pediatrics 2018; 5(5): 1733-1739.

9. Sarma P, Boro RC, Acharjee PS. An analysis of indications of caesarean sections at Tezpur medical college and hospital, Tezpur (a government hospital). Int J Reprod Contracept Obstet Gynecol 2016; 5: 1364-1367.

10. Saxena N, Sharma B. Gupta V et al. A six-year appraisal of caesarean delivery at a teaching hospital in Uttarakhand. Int J Reprod Contracept Obstet Gynecol 2016; 5: 4369-4372.

11. Preetkamal, Kaur $H$, Nagpal M. Is current rising trend of cesarean sections justified? Int J Reprod Contracept Obstet Gynecol 2017; 6: 872-876.

12. Jawa A, Garg S, Tater A et al. Indications and rates of lower segment caesarean section at tertiary care hospital-an analytical study. Int J Reprod Contracept Obstet Gynecol 2016; 5: 3466-3469.

13. Yadav RG, Maitra N. Examining cesarean delivery rates using the Robson's ten group classification. J Obstet Gynecol India 2016; 66(1): 1-6.

14. Subhashini R, Uma N. Changing trends in Caesarean delivery. IAIM 2015; 2(3): 96-102.

15. Santhanalakshmi C, Gnanasekaran V, Chakravarthy AR. A retrospective analysis of cesarean section in a tertiary care hospital. Int J Sci Res 2015; 4: 2097-9. 
16. Desai E, Leuva H, Leuva B et al. A study of primary caesarean section in multipara. Int J Reprod Contracept Obstet Gynecol 2013; 2(3): 320-324.

17. Jain $M$, Patel $A$. A cross sectional study of rate, indications and complications of primary caesarean section. Int J Reprod Contracept Obstet Gynecol 2016; 5(6): 1814-1819.

18. Chavda D, Goswami K, Dudhrejiva K. A cross sectional study of 1000 lower segment cesarean section in obstetrics and gynecology department of P. D. U Medical College, Rajkot, Gujarat, India. Int J Reprod Contracept Obstet Gynecol 2017; 6(4): 1186-91.

19. Bade $P$, Kendre $V$, Jadhav $Y$ et al. An analysis of indications for caesarean section at government medical college, Latur. Intern J Recent Trends Sci Technol 2014; 11(1): 6-8.

20. Singh G, Gupta ED. Rising incidence of caesarean section in rural area in Haryana, India: a retrospective analysis. Internet J Gynecol Obstet 2013; 17(2): 1-5.

21. Shiba M, Sachin P, Niranjan M et al. Trends in cesarean delivery: rate and indications. J Obstet Gynecol 2014; 64(4): 251-254.

22. Shabnam S. Caesarean section delivery in India: causes and concerns. International Union for the Scientific Study of Population, Assessments of Facility-based Delivery Services. Available from: https://iussp. org/sites/default/files/event_call_for_pa pers/ Caesarean\%20section\%20delivery\%20in\%20India_0. pdf. 